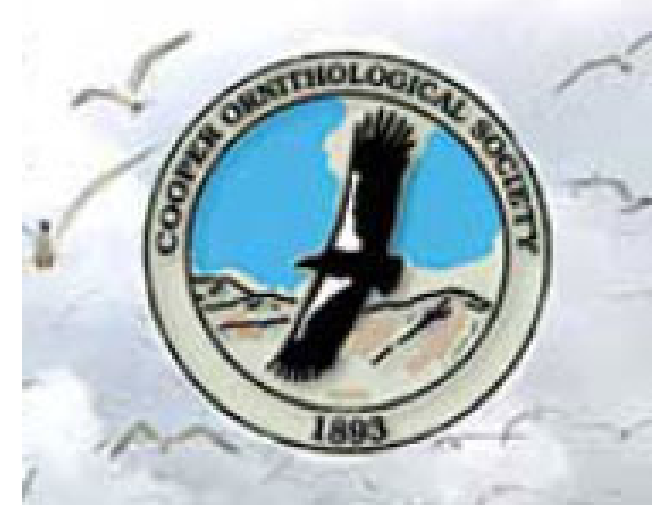

Life History Studies of the Lesser Snow Goose V.: Temporal Effects on Age-Specific Fecundity Author(s): Robert F. Rockwell, C. Scott Findlay, Fred Cooke

Reviewed work(s):

Source: The Condor, Vol. 87, No. 1 (Feb., 1985), pp. 142-143

Published by: University of California Press on behalf of the Cooper Ornithological Society

Stable URL: http://www.jstor.org/stable/1367145

Accessed: 24/04/2012 00:57

Your use of the JSTOR archive indicates your acceptance of the Terms \& Conditions of Use, available at http://www.jstor.org/page/info/about/policies/terms.jsp

JSTOR is a not-for-profit service that helps scholars, researchers, and students discover, use, and build upon a wide range of content in a trusted digital archive. We use information technology and tools to increase productivity and facilitate new forms of scholarship. For more information about JSTOR, please contact support@jstor.org. 
The Condor 87:142-143

(c) The Cooper Ornithological Society 1985

\section{LIFE HISTORY STUDIES OF THE LESSER SNOW GOOSE V.: TEMPORAL EFFECTS ON AGE-SPECIFIC FECUNDITY}

\section{ROBERT F. ROCKWELL}

\section{SCOTT FINDLAY}

AND

\section{FRED COOKE}

Age is known to influence fecundity in many avian species Rockwell et al. (1983) showed that the clutch size of female Lesser Snow Geese (Chen caerulescens caerulescens) increases gradually up to age five, after which there are no detectable age effects. Furthermore, they documented considerable yearly variation in the mean clutch size at the La Pérouse Bay colony near Churchill, Manitoba; this variation could not be attributed to annual differences in the age composition of the breeding females. Instead, they suggested that some temporally variable environmental condition(s) might be affecting the size of the initial clutch laid, the level of partial clutch loss, or some combination of the two. A question that arises is whether the proximate factors resulting in these yearly changes in mean fecundity affect all age classes to the same extent. Are, for example, young and inexperienced females less able to cope with the exigencies of particularly severe breeding seasons? Such a finding would require refinement of the emerging theories that relate average reproductive output of young females to general life-history tactics (e.g., Curio 1983). In addition, a general dependence of yearly fecundity differences on age would complicate models of population dynamics of this species (cf. Findlay et al. 1982). In this paper, we examine this issue by evaluating annual variation in the difference between mean clutch sizes of twoyear-old and older females.

\section{MATERIALS AND METHODS}

We collected data as part of a larger investigation of the breeding biology of the Lesser Snow Goose at La Pérouse Bay. Details of the study site, general breeding biology and data collection methods are available in Cooke et al. (in press). We are interested here in clutch sizes of knownage individuals and have used the total number of eggs present in the nest at hatch (Clutch Size at $H$ atch) as the measure of fecundity (Cooke et al., in press). Relative reduction in $\mathrm{CSH}$ for any given breeding season is defined as the difference between the mean CSH of females age five and greater, and the CSH of each two year old. We chose five as the minimum age limit because 1) age classes five and greater form a homogeneous set for this measure of fecundity (Rockwell et al. 1983), and 2) age class five is the youngest class composed almost entirely of experienced breeders (Sulzbach 1975).

\section{RESULTS AND DISCUSSION}

The relative reduction of clutch size at hatching of twoyear-old female Lesser Snow Geese fluctuated annually (Fig. 1). While the relative performance of two-year-olds was always less than that of females five and older, the level of reduction varied significantly over the breeding seasons (1-way ANOVA: $F=2.42 ; \mathrm{df}=8,186 ; P \leq 0.025$ ).
This result is unexpected in view of the analyses of Rockwell et al. (1983). Although those analyses clearly demonstrated both age and time effects on absolute clutch size, the effects of these factors were independent. That independence was inferred from nonsignificance of the general age-by-time interaction terms in the analyses and implies, for example, that relative differences in clutch size among age classes should not vary significantly over time. The inconsistency between the implication and the present result reflects, in part, the lower power of the type of factorial ANOVA approach often required for the analysis of field data (see Rockwell et al. 1983 for details). The inconsistency does not result from the inclusion of two additional years' data (1981 and 1982) in the present analysis, since exclusion of those data does not alter the outcome of the ANOVA of relative reduction in clutch size $(F=2.75 ; \mathrm{df}=6,131 ; P \leq 0.025)$. The age-by-time interaction indicated by the present analysis is quite specific. Hence, while age and time effects may be independent over wider and more general ranges, specific exceptions clearly exist. This case exemplifies the importance of using additional analyses when general results are to be applied to specific situations.

In selecting proximate factors whose temporal fluctuations might be related to the yearly differences in relative performance of two-year-olds, we must consider the biological nature of the measure of fecundity. Fecundity differences based on clutch size at hatching, be they agespecific reductions or temporal variation in such reductions, may reflect, for example, differences in nutrient acquisition needed for clutch production (Rockwell et al. 1983). Alternatively, they may represent differences in nest attentiveness required to reduce predation during the initiation and incubation periods. As such, the factors we have examined include those that could be related to one or both of these aspects of the measured fecundity (Table 1).

Davies and Cooke (1983) determined that 1977 and 1980 were years of severe spring Canadian prairie drought. The relative clutch reductions differed in those two years (Fig. 1), with 1977 being the year of least reduction overall. It is, therefore, unlikely that this factor is solely responsible for temporal fluctuation in the relative reduction of clutch sizes of two-year-olds. Potential associations with other factors were evaluated with product-moment correlation

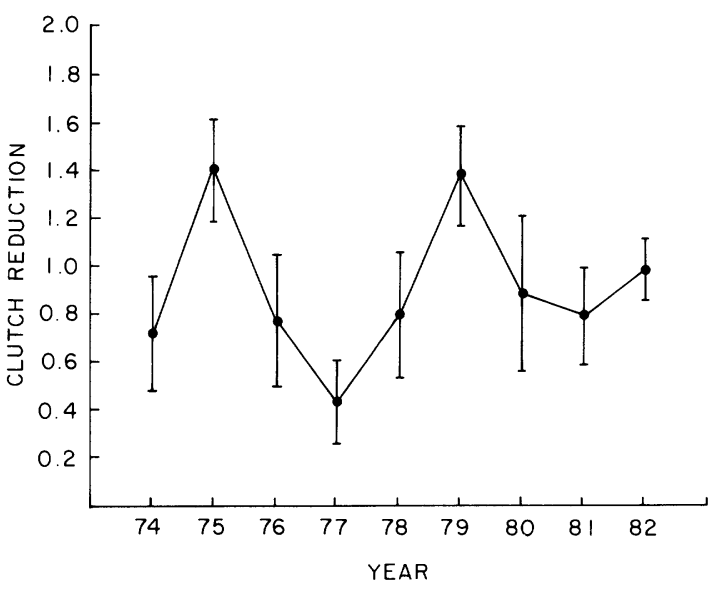

FIGURE 1. Yearly fluctuations in the relative reduction of clutch sizes of two-year-old Lesser Snow Geese. Values are \pm 1 standard error. 
TABLE 1. Correlations between the relative reduction of clutch size of two-year-old females and specific environmental factors.

\begin{tabular}{|c|c|c|c|}
\hline Factor & Potential influence on relative reduction & Reference & $\frac{\text { Correlation }}{r(\mathrm{df})}$ \\
\hline $\begin{array}{l}\text { Spring prairie } \\
\text { drought }\end{array}$ & $\begin{array}{l}\text { Drought conditions affect nutrient reserve accumulation, } \\
\text { and hence initial clutch size }\end{array}$ & $\begin{array}{l}\text { Davies and } \\
\text { Cooke } 1983\end{array}$ & \\
\hline $\begin{array}{l}\text { Season phenology: } \\
\text { Initiation date }\end{array}$ & Initial clutch size decreases as season progresses & $\begin{array}{l}\text { Findlay and } \\
\text { Cooke } 1983\end{array}$ & $0.29(5)^{\mathrm{a}}$ \\
\hline Hatch date & & $\begin{array}{l}\text { Davies and } \\
\text { Cooke } 1983 \\
\text { Hamann } 1983\end{array}$ & $0.16(5)$ \\
\hline $\begin{array}{l}\text { Proportion of } \\
\text { two-year-olds in } \\
\text { population }\end{array}$ & $\begin{array}{l}\text { Poor conditions reduce proportion of two-year-old breed- } \\
\text { ers. Potentially, those who do breed are higher quality in- } \\
\text { dividuals producing larger-than-average clutches }\end{array}$ & $\begin{array}{l}\text { Davies and } \\
\text { Cooke } 1983\end{array}$ & $0.25(6)$ \\
\hline Population size & $\begin{array}{l}\text { Density-related competition for available nest sites differen- } \\
\text { tially affects younger individuals, causing them to initiate } \\
\text { later and hence, produce small clutches }\end{array}$ & $\begin{array}{l}\text { Cooke et al. } \\
1983\end{array}$ & $0.21(7)$ \\
\hline $\begin{array}{l}\text { Intraspecific } \\
\text { nest parasitism }\end{array}$ & $\begin{array}{l}\text { Younger females are possibly more susceptible to intra-spe- } \\
\text { cific nest parasitism }\end{array}$ & $\begin{array}{l}\text { Finney and } \\
\text { Cooke } 1978\end{array}$ & $-0.53(7)$ \\
\hline
\end{tabular}

- df varies among factors because estimates of some factors not available for all years.

b Based on projections from census analyses of females banded as goslings.

(Table 1). Even though the correlation for intraspecific nest parasitism is intriguingly large, none of the coefficients are statistically significant. Although some other single environmental factor may be responsible for temporal variation in the relative performance of two-year-old females we believe it more likely that the pattern is related to some combination of factors, which may well act in a threshold $\rightarrow$ rather than a continuous, fashion. Some breeding seasons disproportionately affect the relative fecundity of young, inexperienced females, but the proximate factor(s) remain to be identified.

Lesser Snow Geese breed in harsh and unpredictable environments, so it is not unexpected that vital rates vary over time. Somewhat surprisingly, however, the influence of environmental factors is biased towards specific age classes. Taken together, our findings bear importantly on the construction of predictive population models. Considering our results in light of Cohen's (1979) work on demographic theory, we conclude that the La Pérouse Bay population of Lesser Snow Geese will probably not achieve either a stable age distribution or a stable yearly growth rate (i.e., it will not behave according to Cohen's strong ergodic theorem). Such instability in the age distribution and growth rate severely complicates both the construction of population models and the estimation of productivity. We believe that such complications, resulting from temporal dependence of vital statistics like fecundity, are not peculiar to this population of the species.

\section{LITERATURE CITED}

$\rightarrow$ Cohen, J. E. 1979. Ergodic theorems in demography. Bull. Am. Math. Soc. 1:275-295.

$\rightarrow$ Cooke, F., C. S. Findlay, R. F. Rockwell, and K. F. ABRAHAM. 1983. Life history studies of the Lesser Snow Goose (Anser caerulescens caerulescens) II. Colony structure. Behav. Ecol. Sociobiol. 12:153-159.

Cooke, F., C. S. Findlay, R. F. Rockwell, and J. A.
SMITH. In press. Life history studies of the Lesser Snow goose (Anser caerulescens caerulescens) III. The selective value of plumage polymorphism: net fecundity. Evolution.

Curio, E. 1983. Why do young birds produce less well? Ibis 125:400-404.

Davies, J. C., AND F. CoOKe. 1983. Annual nesting productivity in snow geese: prairie droughts and arctic springs. J. Wildl. Manage. 47:291-296.

Findlay, C. S., AND F. CoOKE. 1983. Genetic and environmental components of clutch size variance in a wild population of Lesser Snow Geese. Evolution 37:724-734.

Findlay, C. S., R. F. Rockwell, and F. Cooke. 1982. Concerning the time dependence of population vital rates. Lect. Notes Biomath. 52:146-153.

FINNEY, G. H., AND F. COOKE. 1978. Reproductive habits in the Snow Goose: the influence of female age. Condor 80:147-158.

HAMANN, J. 1983. Intra-seasonal clutch size reduction in Lesser Snow Geese. Unpubl. M.Sc. thesis, Queen's Univ., Kingston, Ontario.

Rockwell, R. F., C. S. Findlay, and F. Cooke. 1983. Life history studies of the Lesser Snow Goose (Anser caerulescens caerulescens) I. The influence of age and time on fecundity. Oecologia 56:318-322.

Sulzbach, D. S. 1975. A study of the population dynamics of a nesting colony of the Lesser Snow Goose (Anser caerulescens caerulescens). Unpubl. M.Sc. thesis, Queen's Univ., Kingston, Ontario.

Department of Biology, City College of New York, 138th Street and Convent Avenue, New York, New York 10031. Address of second and third authors: Department of Biology, Queen's University, Kingston, Ontario K7L 3N6, Canada. Received 28 November 1983. Final acceptance 29 May 1984. 